\title{
The Influence of Teacher's Supervision and Professionalism on Teacher's Performance
}

\author{
Muhammad Yusuf \\ SMA Al-Hijra Yayasan Ibu \\ e-mail: muhamad.yus642@gmail.com \\ Happy Fitria \\ Universitas PGRI Palembang \\ e-mail: happyfitriamufly@univpgri-palembang.ac.id \\ Mulyadi \\ Universitas PGRI Palembang \\ e-mail:mulyadi@univpgri-palembang.ac.id \\ Article History: Received on 1 December 2020, Revised on 8 January 2021, \\ Published on 21 January 2021
}

\begin{abstract}
This study determined the effect of supervision and professionalism on teacher performance in State Junior High Schools of SP. Padang. This research uses quantitative methods. The population in this study were all junior high school teachers with the status of Civil Servants in SP. Padang. While the sample was obtained by totaling sampling technique with 51 respondents. Data collected by documentation, questionnaires, and observations. Data analysis techniques using simple linear regression formula and multiple linear regression with the help of SPSS software. The results of the study concluded that there was an influence of supervision and on the teacher performance of the State Junior High Schools of SP. Padang. There is an influence of teacher professionalism on teacher performance in State Junior High Schools of SP. Padang. There is an influence of teacher supervision and professionalism together on the teacher performance of State Junior High Schools of SP. Padang.
\end{abstract}

Keywords: Supervision, Teacher Professionalism, Teacher's Performance

\section{A. Introduction}

Education is a long-term investment in human resources that has strategic value for the continuity of human civilization in the world. Quality human resources can be realized with a good educational process and from quality educational institutions (Rahmadoni, 2018; Asvio et al, 2019). Therefore, almost all countries place the education variable as something important and main in the context of nation and state development. Likewise, Indonesia places education as something important and foremost (Herabudin, 2009).

The teacher has a mission and a tough task, but it is noble to bring the nation's buds to the peak of their dreams. The ability of teachers to attract students' interest in learning is the initial stage of a meaningful learning process that can make students active and motivated to develop all abilities in the classroom. Therefore, it is appropriate for teachers to have various competences, professionalism, and teacher performance related to their duties and responsibilities. The teacher will show an interest in following a task or activity and then carry it out well, if there 
Volume 1 (3) 2020

E-ISSN: 2723-6919 P-ISSN:2746-0827

is a driving factor, namely motivation (Darmiati et al, 2020). With good teacher competence and good performance, it will be a professional one, both academically and non-academically (Herabudin, 2009). Performance issues are always a major concern in educational institutions I schools because they affect the productivity of these schools. Professional teachers arebelieved to be able to make student think, behave an act creatively (Ruslan et al, 2020).

Professional teachers are the main keys to smooth and successful learning. Because only professional teachers can create an active situation for students in learning activities. Professional teacher believed to be able to deliver students in learning to find, manage, integrate their acquisition, and solve problems related to knowledge, attitudes, and values or life skills (Salwa et al, 2019). The less than optimal performance of teachers in schools is not entirely caused by the ability of the teachers themselves (Maryati et al, 2020).

The purpose of this research is to see whether there is an effect of teacher supervision and professionalism on teacher performance. Professional teachers have social responsibility manifested through teacher competence from the social environment and have effective interactive skills. It must be addressed by increasing qualifications and competence, especially now that there is a need to take a certification exam to determine the eligibility of a teacher. Therefore, teachers should not be exposed to the "routine trap" where teachers must be prepared with daily activities so that they forget to increase their competence and professionalism. (Purwanto, 2017). Teacher performance will be optimal if it is integrated with school components, whether it is the principal or students.

According to Herabudin (2009) education is a branch of science in general. Worse, educational experts have begun to realize that although the principles in various fields have similarities, both in process and in their objectives, in the world of education there are specificities that cannot be equated with other worlds, only that educators and students are two human figures that cannot be separated from education World. Educators, a substantial definition of education, are people who have the knowledge and skills to know their students. This influence comes from adults (created people and parts of it) and is shown to immature people. In an Indonesian perspective, the meaning, function, and objectives of education are formulated in the national education system law number 20 of 2003 in articles 1 and 3 education is a conscious and planned effort to show the learning atmosphere and learning process so that students can actively develop their potential to have religious spiritual strength, self-control, personality, which is needed by oneself, society, nation and state. In the aspect of teachers, students, and teaching materials are the dominant elements in the learning process in the classroom. National education functions to develop abilities and shape the character and civilization of the nation, aiming at developing the potential of students to become human beings who believe and fear the one and only God, have noble character, are healthy, knowledgeable, creative, independent, and become democratic and responsible citizen.

Responsibility is the main requirement in leadership. Without a sense of responsibility, people cannot be leaders. In everyday life, responsibility is often misinterpreted. People say responsible which actually only means daring to "give responsibility" or reprimand their actions, even if their actions are wrong or not good. A person in a leadership position has the ability to read the situation to be faced and adjust his leadership style to the demands of the situation he is facing, even though this adjustment is only temporary (Astuti et al, 2020). Leadership includes three meanings, namely effort, the ability to run a business, and an authority that makes someone considered capable of leading. Institutional leaders must be able 
to play an active role and be able to strategically position themselves in directing the institution. The success and effectiveness of a school principal in leading can be pursued by respecting each other, working together and having knowledge about the behavior of subordinates (Rahmadoni, 2018).

Responsibility is a meaning that contains ethical, social, and scientific norms, which means that responsible actions are good, can be accepted and approved by other people, and contain general truths (Purwanto, 2017). Supervision is in accordance with the development of society and the development of education in our country, Indonesia since the Dutch colonial era until the era of independence until now, the obligations and responsibilities of educational leaders in general and principals in particular have developed and changed as well. The leadership of the principal is very supportive of achieving effective and efficient school management.

The principal as the leader of the educational institution functions as the person in charge of all educational activities in the school (Agustina et al, 2021). The duties of the principal, in addition to regulating the running of the school, must also be able to work together and have a close relationship with the community. He is obliged to inspire the enthusiasm of the staff, teachers and school employees to work better; build and maintain kinship, cohesiveness and unity between teachers, employees and students; developing school curriculum, knowing school design and knowing how to run it; pay attention and seek the welfare of teachers and employees; and so on. The principal as an education administrator is responsible for the smooth implementation of education and teaching in his school. Therefore, to be able to carry out the objectives well, the head of the school should understand, master, and be able to carry out activities related to his function as an educational administrator. The duties of the principal towards teachers and school employees see this definition, so the principal's duty as a supervisor means that he should be good at researching, dancing, and determining which conditions are needed for the progress of his school as much as possible (Purwanto, 2017).

The need for increased performance as an effort to improve the quality and quality of education in SMP Negeri in SP sub-district. Padang. In fact, in the field, based on the results of interviews with the principal, that the problems of supervision, teacher professionalism, and teacher performance need serious attention and handling that involves all elements and stakeholders in education in general, more specifically in public junior high schools in SP sub-district. Padang.

Now, the provision of education is more decentralized to regions: the community is involved and participates in educational efforts, and so on. The responsibilities of principals and teachers may be many and broad. If in the past, the principal was considered good and sufficient if the school could run regularly regardless of the interests and relationships with the surrounding community, then the current assessment is more than that.

To explain what leadership means, it will be stated first from the point of view of which a person views or understands the nature of leadership, and then, based on that understanding, it will be seen how he formulates or defines it. Leader comes from the word "leader" and leadership comes from the word "leadership". The leader is a result-oriented person, results are obtained when the leader knows what he wants. Leader is a person who has certain superiority, so that he has the authority and power to move others to make joint efforts to achieve certain goals. 
The teacher is an educator, mentor, coach, and leader who can create an attractive learning climate, provide a sense of security, comfort and conducive to the classroom. Its presence in the midst of students can break the atmosphere of coldness, stiffness, and boredom of learning that students feel hard to accept. Such conditions certainly require the skills of a teacher, and not all are able to do it. Realizing this, the authors consider that the existence of professional teachers is very necessary (Hamalik, 2011).

The research on the effect of teacher supervision and professionalism on teacher performance in SMP Negeri in SP. Padang sub-district to be conducted is a correlational quantitative research (cause-and-effect). This type of correlational research aims to determine the existence of a cause-and-effect relationship that affects each other and is related between research variables. This study consisted of three variables in the form of three independent variables and one dependent variable. The independent variable in this study is in the form of teacher supervision and previsionalism on teacher performance, while the dependent variable in this study is the performance of the teachers at SMP Negeri in SP. Padang District.

Being a teacher is not an easy job, as some people imagine, by mastering the material and conveying it to students is enough, this cannot be categorized as a teacher who has a professional job, because a professional teacher, they must have various skills, special abilities, loves their job, maintains the teacher's code of ethics, and so on.

\section{B. Methods}

The research on the effect of teacher supervision and professionalism on teacher performance in SMP Negeri in SP. Padang sub-district to be conducted is a correlational quantitative research (cause-and-effect). This type of correlational research aims to determine the existence of a cause-and-effect relationship that affects each other and is related between research variables. This study consisted of three variables in the form of three independent variables and one dependent variable. The independent variable in this study is in the form of teacher supervision and previsionalism on teacher performance, while the dependent variable in this study is the performance of the teachers at SMP Negeri in SP. Padang District.

This research uses quantitative methods. The population in this study were all junior high school teachers with the status of Civil Servants in the SP District. Padang. While the sample obtained by totaling sampling technique as many as 51 respondents. Data collection was carried out by means of documentation, questionnaires, and observations. The data analysis technique used a simple linear regression formula and multiple linear regression with the help of SPSS software.

\section{Results and Discussion}

From the research results show that supervision has a significant effect on performance. These results support the hypothesis proposed that supervision has a significant effect on performance. According to the results of calculations based on the regression equation based on the regression equation (coefficient), it can be explained that if the value of supervision $\left(\mathrm{X}_{1}\right)$ increases by 1 unit score, then performance (Y) will increase by 3,872, 1 unit score with the provisions of constant supervision $\left(\mathrm{X}_{1}\right)$. Regarding whether there is a significant influence between supervision $\left(\mathrm{X}_{1}\right)$ on performance $(\mathrm{Y})$, it can be seen in the size of the t-count value found in table 4.13. The value of supervision t count is 3,942 with a significant value of 0,000 
Volume 1 (3) 2020

E-ISSN: 2723-6919 P-ISSN:2746-0827

$(\mathrm{p}<0.05)$ with $\mathrm{t}$ table of 2.011 or in other words $\mathrm{t}$ count $>\mathrm{t}$ table, then rejects $\mathrm{H} 0$ and accepts $\mathrm{Ha}$ or in other words this shows that there is a significant influence between the supervision variables $\left(\mathrm{X}_{1}\right)$ on performance $(\mathrm{Y})$.

The results of this study prove that teachers are imperfect individuals and social beings who need help from others close to themselves to assist them in carrying out their duties and responsibilities, in this case the teacher's competence is influenced by the effectiveness of the principal's supervision at the school. The results of this study are in line with the research of Wiryanto (2002) which concludes that there is a positive relationship between teacher perceptions of the principal's supervision and teacher teaching effectiveness, the level of strength of the relationship is 0.85 and the effective contribution is $72.64 \%$.

The results of the study show that professionalism has a significant effect on performance. These results also support the hypothesis that professionalism has a significant effect on performance. The regression results explained that if the value of professionalism $\left(\mathrm{X}_{2}\right)$ increases by 1 unit score, then the performance (Y) will increase by 0.566 units of score, provided that the value of professionalism $\left(\mathrm{X}_{2}\right)$ is constant. Regarding whether there is a significant influence, it can be seen in table 4.13 with the tcount of professionalism $\left(\mathrm{X}_{2}\right)$ of 5.607 with a significant level of 0.001 ( $\mathrm{p}<0.05)$, then rejecting H0 shows that there is a significant influence between professionalism $\left(\mathrm{X}_{2}\right)$ on performance $(\mathrm{Y})$. This shows that professionalism $\left(\mathrm{X}_{2}\right)$ affects performance $(\mathrm{Y})$.

The results of the study show that supervision and professionalism have a significant effect on performance. These results support the hypothesis that supervision and professionalism have a significant effect on performance.

By taking a significant level of 0.004 ( $\mathrm{p}<0.05)$, then $\mathrm{H} 0$ is rejected and $\mathrm{Ha}$ is accepted, this can be seen from the F test conducted where Fcount is 80.233> Ftable is 3.267. This means that it can be concluded that there is a simultaneous influence between supervision and professionalism on performance and shows a positive relationship between supervision and professionalism on performance. This shows that the variables of supervision and professionalism affect performance together.

\section{Conclusion}

Based on the results of data analysis, it can be concluded that: 1) there is an effect of supervision on teacher performance in SMP Negeri Kecamatan SP. Padang is proven to be true where the value of tcount $>$ ttable or $3,942>2,011 ; 2$ ) there is an effect of teacher professionalism on teacher performance in SMP Negeri Kecamatan SP. Padang is proven to be true where the value of tcount $>$ ttable or 5.960> 2.011, and 3) there is a joint effect of teacher supervision and professionalism on teacher performance where the value of fcount> ftabel or 80.233>3.267.

\section{E. Acknowledgement}

Our deepest gratitude goes to the Principal of SMA Al-Hijra Yayasan Ibu, Chancellor of the PGRI Palembang University, Director of the PGRI Palembang University Postgraduate 
Volume 1 (3) 2020

E-ISSN: 2723-6919 P-ISSN:2746-0827

Program and the PGRI Palembang University Education Management Study Program who have supported us to do this extraordinary thing. This project is independently funded. We would also like to thank our friends in Education Management who helped us a lot in completing this project in a limited time frame.

\section{References}

Agustina, M., Kristiawan, M., \& Tobari. (2021). The Influence of Principal's Leadership and School's Climate on The Work Productivity of Vocational Pharmacy Teachers in Indonesia. International Journal of Educational Review 3(1), 63-76.

Astuti, R. W., Fitria, H., \& Rohana, R. (2020). The Influence of Leadership Styles and Work Motivation on Teacher's Performance. Journal of Social Work and Science Education, 1(2), 105-114. Retrieved from https://ejournal.karinosseff.org/index.php/jswse/article/view/33

Asvio, N., Yamin, M., \& Risnita. (2019). Influence of Leadership Style, Emotional Intelligence and Job Satisfaction toward Organizational Commitment (Survey at SMA Muhammadiyah South Sumatera). International Journal of Scientific \& Technology Research 8 (8).

Darmiati, D., Kristiawan, M., \& Rohana, R. (2020). The Influence of School Leadership and Work Motivation toward Teacher's Discipline. Journal of Social Work and Science Education, 1(1), 32-44. Retrieved from https://ejournal.karinosseff.org/index.php/jswse/article/view/8

Hamalik, O. (2011). Proses Pendidikan [Educational Process]. Jakarta: Rineka Cipta.

Herabudin. (2009). Adimistrasi Dan Supervisi Pendidikan [Education Administration and Supervision]. Bandung: CV Pustaka Setia.

Maryati, E., Fitria, H., \& Rohana, R. (2020). The Influence of Principal's Leadership Style and Organizational Culture on Teacher's Performance. Journal of Social Work and Science Education, 1(2), 127-139. Retrieved from https://ejournal.karinosseff.org/index.php/jswse/article/view/38

Purwanto, M. N. (2017). Adimistrasi dan Supervisi Pendidikan [Educational Administration and Supervision]. Bandung: Remaja Rosdakarya.

Rahmadoni, J. (2018). Isu Global Manajemen Pembiayaan Pendidikan di SD Indonesian Creative School Pekanbaru. Jurnal Manajemen, Kepemimpinan dan Supervisi Pendidikan 3(2), Juli-Desember 2018.

Ruslan, Lian, B., \& Fitria, H. (2020). The Influence o Principal's Situational Leadership and Teacher's Professionalism on Teacher's Performance. International Journal of Progressive Sciences and Technologies (IJPSAT), 20(1). 
Journal of Social Work and Science Education

Volume 1 (3) 2020

E-ISSN: 2723-6919 P-ISSN:2746-0827

Salwa., Kristiawan, M., \& Lian, B. (2019). The Effect ofAcademic Qualification, Work Experience and Work Motivation towards Primary School Principal Performance. International Journal of Scientific \& Technology Research, 8(8). 